\title{
A COMÉDIA NA POÉTICA DE ARISTÓTELES
}

\author{
Pierre Destrée ${ }^{* 1}$
}

RESUMO: This paper tries to reconstruct what might have been Aristotle's theory of comedy. Through the analysis of the actual text of the Poetics, along with some other texts of Aristotle, I draw conclusions regarding the nature of comedy and laughter in Aristotle's thinking, and reflect upon subjects there implied, such as what would be the role played by katharsis in comedy and the emotions proper to comedy.

PALAVRAS-CHAVE: Aristóteles, Comédia, Katharsis, Teatro Grego.

A comédia, como todas as pessoas do mundo sabem a partir do famoso romance de Umberto Eco, era o tema do segundo livro da Poética de Aristóteles. Esse segundo livro, ou mais precisamente o segundo volumen (rolo de papiro), do "livro" ou tratado sobre a Poesia perdeu-se definitivamente em algum momento da Antiguidade ou no começo da Idade Média. Não possuímos nenhuma pista que nos permita restringir esse período de tempo. A única coisa que sabemos com certeza é que uma tradução siríaca apenas do primeiro livro foi feita no final do século $9^{\circ}$, que indica quase certamente que a perda ocorreu antes. Muito infelizmente, essa perda ocorreu sem muito alarde e sem deixar muitos vestígios para trás. Os únicos vestígios confiáveis que temos são, principalmente, a menção à existência do segundo livro feita pelo próprio Aristóteles, que se refere a ele duas vezes na sua Retórica (e também provavelmente na Política VIII 7) e as listas de obras de Aristóteles em Diógenes Laércio e Hesíquio.

Acerca de seu conteúdo, não temos mais do que duas breves referências a uma "katharsis cômica" por Jâmblico e Proclo, sem nomearem Aristóteles ou a Poética. No entanto, é geralmente aceito que ambos pertencem à obra "exotérica" Sobre os Poetas, isto é, uma obra publicada por Aristóteles para um público externo à sua escola, possivelmente maior do que aquele com que ele lidou no segundo livro da Poética. Em adição a esses poucos vestígios, há ainda um texto muito famoso, o Tractatus Coislinianus (nomeado a partir do Cardeal Coislin, a quem ele pertencia, antes de ir para a Biblioteca Nacional de Paris) que oferece o que parece ser um sumário desse segundo livro sobre a comédia. Infelizmente, esse texto apresenta problemas de interpretação numerosos, e provavelmente insolúveis, uma vez que suas passagens mais relevantes se chocam com o que nós temos na Poética. Portanto, geralmente se aceita (contrariamente a Janko, 1984, que defende tratar-se de um sumário do segundo livro da Poética genuíno e, portanto, confiável) que esse texto é

\footnotetext{
* $\quad$ Professor da Univesité Catholique de Louvain e pesquisador do FNRS.

1 Desejo expressar minha gratidão ao Professor Otfried Höffe, ao Senhor Dammaschke e à Akademia Verlag pela permissão de republicar este artigo, que apareceu originalmente com o título "Die Kömodie" em O. Höffe (ed.), Aristoteles: Poetik, Klassiker Aulegen, Band 38, Berlin, Akademia Verlag, 2010, pp. 69-86 [Nota do Tradutor: as citações feitas pelo autor são traduzidas a partir da tradução para o inglês apresentada por ele, a fim de respeitar suas opções].
} 
ou uma falsificação criada por algum erudito bizantino que queria completar a nossa Poética (Bernays, 1853), ou um sumário desse segundo livro no mínimo distorcido e, portanto, inconfiável (Heath, 1989). Conseqüentemente, o único caminho indubitavelmente confiável que temos, se quisermos reconstruir o que Aristóteles poderia ter dito no segundo livro da sua Poética sobre a comédia, é fazê-lo a partir das numerosas, embora vagas, passagens sobre a comédia no primeiro livro da Poética.

Nesta contribuição, gostaria de oferecer uma reconstrução grosseira (possível) de alguns pontos centrais da teoria da comédia de Aristóteles a partir das afirmações explícitas que ele faz na Poética tal como a temos, acrescentando algumas passagens importantes da sua Retórica, bem como da Política. Tentarei esclarecer alguns dos principais conceitos da comédia que Aristóteles menciona rapidamente no quinto capítulo, tais como "risível" (geloion) e "erro" ou "falta" (hamartêma). Também tentarei reconstruir o que Aristóteles poderia ter dito acerca de outros conceitos principais que não encontramos na nossa Poética, mas que deveriam ter tido um papel significativo no segundo livro, como as emoções próprias da comédia e sua katharsis. Mas, antes de fazer isso, eu gostaria de esclarecer a importância da comédia na teoria poética de Aristóteles.

\section{A IMPORTÂNCIA DA COMÉDIA NA “ARTE DA POESIA"}

Mesmo um breve olhar sobre a enorme literatura acadêmica acerca da Poética desde, digamos, os famosos estudos de Jacob Bernays em meado do século 19 é suficiente para deixar claro que o tema da comédia sofre de relativa negligência e desinteresse por parte de muitos intérpretes. Pode-se entender perfeitamente por que os intérpretes não deram tanta atenção à comédia: a falta de informação é sem dúvida um dos maiores obstáculos. Mas como se pode explicar que muitas introduções à Poética não mencionam ou, pelo menos, não dedicam mais do que algumas linhas à comédia? Ou que a maioria das traduções não verta, ou sequer mencione, as últimas palavras, dadas por um dos nossos dois manuscritos, que parecem anunciar o início do segundo livro (“Acerca dos escárnios e da comédia...”)? Ou que alguns (Lanza, 1987) até mesmo tentaram, além de toda evidência, argumentar que Aristóteles na verdade não escreveu o segundo livro, como se a comédia fosse um tema fútil demais para merecer uma investigação filosófica própria completa? Nada mais, creio eu, do que um juízo de valor bastante difundido (mesmo que não explicitamente expresso) entre os especialistas: a tragédia é a melhor forma de poesia segundo Aristóteles e, como consequiência, a comédia ocupa apenas uma posição secundária. Mesmo quando reconhecem a existência de um segundo livro sobre a comédia, muitos especialistas parecem pensar que a comédia não poderia ter a mesma importância da tragédia; e alguns intérpretes chegam a pensar que as numerosas menções à comédia na nossa Poética, principalmente nos cinco primeiros capítulos, deve-se apenas, ou pelo menos primariamente, ao intuito de distinguir, tanto em sentido descritivo quanto normativo, a tragédia de outros tipos de poesia. Eu gostaria de questionar radicalmente essa suposição difundida que considero um mero preconceito sem nenhum elemento de prova a partir do próprio texto da Poética.

A principal afirmação que pode ter levado a esse preconceito é esta: que a tragédia é mimêsis de uma ação "elevada", "nobre", "admirável" ou "importante" (spoudaia praxis) (6, 1449b24), ao passo que a comédia é mimêsis de "pessoas inferiores" (5, 1448b31-31). Desse princípio, devemos supor que uma ação “inferior” é uma ação não admirável ou, pelo menos, uma ação não importante. Se se tende a interpretar a Poética com a ajuda da Ética (como muitos intérpretes o fazem hoje em dia), parece muito difícil não ver a comédia como

Organon, Porto Alegre, $n^{\circ} 49$, julho-dezembro, 2010, p.69 - 94 
um tipo de subproduto da arte ou como uma arte para o povo. Ou de uma outra perspectiva: caso se pense, o que provavelmente seria certo de se fazer, que Aristóteles era um aristocrata que desprezava o povo, não seria necessário, então, aceitar que ele deve ter desprezado uma forma de arte não "elevada" e não importante? Mas essa conclusão não procede. Não há nada no nosso texto da Poética que seja uma prova mínima de um status mais elevado da tragédia, nem de um desprezo pela comédia. Muito pelo contrário: duas passagens importantes mostram muito claramente que Aristóteles considerava que a comédia tem tanto valor quanto a tragédia. Vejamos essas passagens precisamente.

No capítulo cinco (1449a37-49b1), Aristóteles diz que a razão pela qual os estágios iniciais da comédia não são conhecidos é que ela não era tomada seriamente no começo, porque as pessoas não a viam como teatro de valor, "nobre" ou "admirável". E ele o diz em oposição à tragédia, cujos estágios de desenvolvimento nós conhecemos, ou pelo menos não desconhecemos, uma vez que ela era, devemos concluir, objeto de um interesse real desde o início. Isso significa que, agora que o archôn concede um coro aos poetas cômicos (isto é, o archôn designa um cidadão rico que deve financiar a produção da peça), a comédia adquiriu exatamente tanto valor quanto a tragédia. E contra isso Aristóteles nada tem a dizer.

No capítulo nove, encontramos uma avaliação da comédia explicitamente positiva. Aristóteles emprega o mesmo conceito de spoudê, que é algo valioso que deve ser seriamente levado em consideração. Porque o papel, ou função, do poeta é "contar o tipo de coisas que poderia ocorrer e são possíveis em termos de probabilidade ou necessidade", segundo a famosa explicação de Aristóteles, a poesia é "mais filosófica e mais valiosa" (philosophôteron kai spoudaioteron) do que a história, que trata das coisas que realmente aconteceram (1451a36ss.). Seja lá o que for que "filosófico" signifique exatamente aqui (sem nos esquecermos da difícil questão da relação entre isso e o "universal"), é suficientemente claro que Aristóteles dá a entender que a poesia tem mais valor, mais importância do que a história. O contexto indica que Aristóteles tem o poeta trágico e a tragédia em mente, e também Homero, que é nomeado apenas algumas linhas depois, no capítulo oito. Mas isso não quer dizer que épica e tragédia seriam os únicos tipos de poesia implicados aqui. Pois, logo após nossa passagem aqui citada, a comédia é acrescentada como um outro tipo de poesia que "visa o universal". Está claro que a comédia lida com o "universal", em oposição à poesia jâmbica, que lida com indivíduos ("poesia jâmbica" é um outro nome para "escárnio", "sátira" ou "invectiva" (psogos), que visa zombar de alguém; Arquíloco, nunca nomeado na Poética, era um dos mais conhecidos autores de tal poesia).

A lógica do texto sugere que nós devemos supor que com a poesia jâmbica se dá o mesmo que com a história: ela faz piadas sobre aquilo que um determinado indivíduo fez ou que lhe aconteceu. O que é menos claro é a razão dada por Aristóteles, dado que a expressão usada em 1451b11-12 pode ser entendida de dois modos: ela pode significar tanto que "isso agora se tornou claro", referindo-se ao tempo em que a comédia separou-se da poesia jâmbica; ou ela pode significar que "isso é imediatamente óbvio", o que quer dizer a comédia exemplifica "universais" de uma maneira mais clara do que a tragédia. O primeiro entendimento me parece mais natural, dada a menção à poesia jâmbica. Mas, se alguém preferir o segundo, isso seria uma indicação adicional de por que Aristóteles tinha bons motivos para ter a comédia em alta conta. Portanto a conseqüência dessa passagem, seja qual for a leitura dessa expressão, é que a comédia é "mais filosófica e mais valiosa" do que a história, de um modo equivalente ao da tragédia.

Além dessas duas passagens, há uma terceira, famosa e bastante difícil (à qual retornarei adiante), do capítulo quatro, na qual Aristóteles apresenta Homero como o

Organon, Porto Alegre, $n^{\circ} 49$, julho-dezembro, 2010, p.69 - 94 
iniciador tanto da tragédia como da comédia, a Ilíada e a Odisséia sendo para a tragédia o que o Margites é para a comédia. Essa analogia é bem conhecida, talvez tão bem conhecida que nós não tenhamos apreciado completamente seu impacto. Intérpretes tendem a esquecer que, na verdade, essa analogia é muito provavelmente nova, visto que não a encontramos em nenhum lugar antes de Aristóteles, nem em Platão, surpreendentemente; além disso, eles tendem a esquecer o próprio fato de que essa iniciação da comédia por Homero é, de certa forma, paradoxal: não diz Aristóteles (1448a; 1449b), seguindo Platão (Teeteto 152e), que Epicarmo foi o inventor do enredo (mythos) cômico, isto é, da comédia no sentido pleno do termo? Então por que "inventar" aqui Homero como o iniciador da comédia? De um ponto de vista teórico, a adição de Homero é um bom argumento: antes da "invenção" de um enredo "universal" por Epicarmo (e, então, em Atenas, por Crates, que provavelmente o expandiu ou generalizou esse traço), credita-se a Homero ter sido o primeiro a "dramatizar", ou seja, a compor uma mimêsis na qual algumas partes são "dramáticas", são encenadas e não meramente narradas. Em outras palavras, as duas características principais da tragédia são aplicadas à comédia também, o que significa que Aristóteles analisa as duas principais formas de poesia da mesma maneira. Todavia, há duas consequiências implicadas em uma perspectiva avaliativa: primeiro, tanto tragédia quanto comédia são julgadas valiosas por Aristóteles porque ambas abandonaram o modo puramente recitativo da poesia (e é por isso que Aristóteles não leva a poesia lírica em conta) e também o tipo de poesia que trata de indivíduos (sátira, hino e elogio: cf. 1448b27); segundo, e mais importante, uma vez que Homero era o poeta dos "temas elevados" por excelência (1448b34), seria absolutamente estranho pensar que Homero teria também iniciado a comédia, se Aristóteles não considerasse que a comédia era de tanto valor quanto a tragédia.

Agora, claro como deve estar que Aristóteles considerava a comédia tão valiosa quanto a tragédia, devo tentar refutar os dois principais argumentos que decorrem diretamente da distinção a que me referi, isto é, ao fato de que a comédia é representação de "pessoas inferiores": não deveria isso implicar, primeiramente, que os poetas de comédias também são um certo tipo de "pessoas inferiores" e, em segundo lugar, pelo mesmo motivo, que os espectadores (ou leitores) de comédias são pessoas desse tipo também? Essas duas implicações são particularmente desafiadoras para a minha afirmação, dado que ambas parecem ser exatamente o que Aristóteles diz.

Depois dos três primeiros capítulos dedicados aos modos que permitem diferenciar as várias mimêseis, e exatamente após a famosa descrição das duas "causas naturais" da poesia, Aristóteles inicia sua história das formas de poesia, na qual ele esclarece: "a poesia se bifurcou de acordo com os tipos correspondentes de caracteres: pessoas de índole mais séria imitaram ações belas, isto é, as das pessoas belas; pessoas mais vulgares imitaram as ações das pessoas inferiores (esta, inicialmente, compondo invectivas, ao passo que aquelas compuseram hinos e eulogias)" (1448b24-27). E, um pouco adiante, acrescenta: "quando a tragédia e a comédia surgiram, aqueles que se inclinavam para cada um dos tipos de poesia se tornaram, de acordo com suas naturezas, poetas de comédia (em vez de escárnios) ou de tragédia (em vez de épica)" (1449a2-5). Aristóteles segue Platão, ao estabelecer essa dicotomia entre os dois gêneros e ao estabelecer que um poeta pode fazer poesia de um gênero apenas. Mas contrariamente a Platão, que diz no Íon que a causa dessa diferenciação é "a inspiração das Musas" (534c), Aristóteles "naturaliza" essa idéia e insiste na causação natural tanto do início da poesia (dado que as causas da mimêsis são naturais) quanto dessa diferenciação: é a própria natureza do caráter dos poetas que os fazem comporem quer tragédias, quer comédias.

Organon, Porto Alegre, $n^{\circ}$ 49, julho-dezembro, 2010, p.69 - 94 
Então não significa isso que os poetas cômicos são apenas pessoas "vulgares" ou "inferiores", cujas produções literárias não merecem muita atenção, pelo menos quando se é, como obviamente é o público de Aristóteles, uma pessoa de valor? Mas, caso se chegue a essa conclusão, surge imediatamente um paradoxo: como Aristóteles diz, exatamente entre essas duas passagens, que Homero é também o ancestral da comédia, devemos chegar à conclusão absurda de que Homero tanto uma pessoa "boa" quanto uma "inferior"?

$\mathrm{Na}$ verdade, não somos obrigados a interpretar essas passagens de uma maneira peremptoriamente naturalista. No capítulo 17, Aristóteles dá este conselho para a construção de um enredo persuasivo: "deve-se também, tanto quanto possível, elaborar enredos usando gestos, pois uma afinidade natural faz aqueles que têm uma emoção os mais convincentes: alguém que realmente experimenta angústia e raiva encena angústia e raiva mais autenticamente. É por isso que a arte da poesia é própria das pessoas que são naturalmente dotadas ou loucas; destas, as primeiras são adaptáveis (euplastos), mas as segundas podem sair de si mesmas" (1455a29ss.). Sejam quais forem os detalhes dessa passagem (especialmente, a construção da oração é disputada, alguns intérpretes propondo que se leia "dotadas mais do que loucas"), parece-me que a "natureza" que é duas vezes invocada aqui não pode ter o sentido naturalista que supostamente encontramos no capítulo quatro: aqui, a "natureza" do poeta não descreve o tipo de pessoa, nobre ou inferior, que deve necessariamente imitar pessoas nobres ou inferiores, mas se refere ao dom natural de ser "adaptável", isto é, de ser capaz de "imitar" ou "representar" vários, e opostos, tipos de sentimentos e ações. O bom "imitador" de pessoas iradas não é aquele que é normalmente uma pessoa irada, mas aquele que pode facilmente, "naturalmente", personificar tal emoção (nas Tesmoforiantes de Aristófanes, o poeta trágico Agatão faz uma declaração semelhante: cf. 149ss.). Isso nos dá a explicação de por que Homero poderia ser apresentado como o ancestral tanto da tragédia quanto da comédia: ele era exatamente o tipo de pessoa naturalmente dotada capaz de personificar várias emoções e, mais genericamente, várias pessoas ou caracteres. Certamente, o mesmo o verdadeiro se tomamos a Ilíada: se consideramos a mimêsis tanto de Aquiles ou Príamo e Tersites tão poderosa, é porque, segundo o ponto de vista de Aristóteles, Homero era excelente em imitar tanto pessoas virtuosas quanto pessoas inferiores - o que não pode implicar que ele mesmo fosse ambos os tipos de pessoa. Agora, Homero deve ter sido uma exceção, pois nenhum outro poeta é mencionado na Poética por escrever comédias e tragédias também. Mas isso também não implicaria que os escritores cômicos eram pessoas inferiores: eles apenas eram mais dotados para imitar pessoas inferiores do que o eram para pessoas nobres.

Finalmente, temos o status dos espectadores (ou leitores). De acordo com a lógica do ponto de vista, os espectadores de comédias devem ser pessoas "inferiores". Mas essa é uma afirmação que Aristóteles jamais faz explicitamente, mesmo nas passagens em que ele invoca espectadores "inferiores": nesses casos, essa expressão se refere exclusivamente a espectadores não educados que preferem música ruim e tragédias mal apresentadas, isto é, cheias de gestos feitos por maus atores. Mas não temos apenas esse argumento ex silentio. Na Política (VII 17, 1336b20-24), Aristóteles diz: "a lei deveria proibir pessoas mais novas de assistir a espetáculos de invectivas jâmbicas e comédias até que eles atingissem a idade em que lhes é apropriado participar de banquetes e beber vinho, e em que sua educação lhes fará imunes ao dano que provém de tais espetáculos". Isso implica que "pessoas mais velhas", isto é, todos os cidadãos homens, podem assistir a tais espetáculos sem qualquer restrição. Mas isso não é apenas uma declaração descritiva sobre algum costume existente em Atenas ou alhures: como o livro VII (juntamente com o VIII) nos fornece uma visão

Organon, Porto Alegre, n 49, julho-dezembro, 2010, p.69- 94 
normativa de como educar o jovem numa cidade ideal, isso significa que Aristóteles considera as invectivas jâmbicas e a comédia um espetáculo perfeitamente adequado para homens adultos moralmente bons em uma cidade perfeita. Se devemos tomar seriamente o que Aristóteles diz aqui, em sua construção normativa de uma cidade idealmente perfeita, não absolutamente nenhuma razão para pensarmos que a comédia teria sido considerada, $n a$ Poética, adequada a pessoas "inferiores" apenas.

Contudo, há uma passagem na Poética que, a primeira vista, poderia implicar algum juízo de desprezo acerca dos espectadores de comédia. No final do décimo terceiro capítulo, Aristóteles diz que a Odisséia fornece o modelo para um tipo de tragédia pior, no qual pessoas ruins terminam infelizes (como os pretendentes), enquanto pessoas boas terminam felizes (como Odisseu e Penélope). E esse tipo de tragédia ruim, Aristóteles acrescenta, falsamente "parece ser o melhor por causa da fraqueza dos espectadores" (14533a32-33). E ele explica por que esse é o modo errado de compor uma tragédia: "esse não é o prazer a se esperar da tragédia, mas é mais apropriado à comédia, onde aqueles que são os piores inimigos no enredo, como Orestes e Egisto, saem no final como novos amigos e ninguémé morto por ninguém" (a35-40). Seja qual por, por enquanto, o sentido desse exemplo, isso parece implicar que o prazer obtido nessa reconciliação final e esse final feliz não são um bom tipo de prazer e que, portanto, a comédia e seu prazer deveriam ser reservados para os espectadores "fracos, isto é, ruins. Mas essa não é a lógica da passagem: toda ela diz que espectadores "fracos", isto é, espectadores que não conseguem "suportar" o final infeliz, trágico, de uma boa tragédia estão propensos a considerar peças não-trágicas melhores do que peças propriamente trágicas. A oposição aqui não é entre prazer trágico e prazer cômico: a oposição é entre "bons", ou bem-educados, espectadores de tragédia, que podem "suportar" o final trágico (que lhes suscita o "prazer trágico" propriamente), e os nãoeducados, que confundem o prazer trágico e o cômico.

\section{A DEFINIÇÃO DE COMÉDIA NO CAPÍTULO CINCO}

É tempo agora de tentar elucidar a definição de comédia no capítulo cinco: "comédia é, como dissemos, uma imitação [representação] de pessoas inferiores - não, no entanto, em relação a todo tipo de defeito: o risível (to geloion) é uma forma do vergonhoso (to aischron). Pois o risível é um certo erro (hamartêma) ou sinal de vergonha (aischos) que não envolve dor ou morte, como é imediatamente evidente no caso da máscara da comédia: ela é feia (aischron) e distorcida, mas não envolve dor" (1449a32-37).

A principal dificuldade dessa definição e também do problema mais geral de como Aristóteles viu a comédia é descobrir o que exatamente Aristóteles queria dizer com o "risível": devemos entendê-lo de uma forma bastante genérica, como uma espécie sob a qual podemos subsumir diferentes formas, ou tem o "risível" um significado muito mais preciso? Devemos entender aqui "risível", que não tem necessariamente uma conotação valorativa, ou "ridículo", que pode implicar tal conotação negativa? O modo como se traduz geloion é de máxima importância, pois a escolha entre "ridículo" e "risível" (ou "cômico") determina inteiramente o modo como se interpreta o entendimento que tem Aristóteles da comédia.

Em paralelo a essa questão, há ainda o problema da melhor comédia: como Aristóteles fala repetidamente que a "melhor" ou "mais bela" tragédia (kallistê tragôdia) é a que preenche melhor a função própria da tragédia (isto é, produzir as emoções "medo" e "compaixão" e o desejo específico que delas resulta), surge a questão: há uma "comédia melhor", que suscita melhor o desejo próprio da Comédia? que tipo de comédia teria ele

Organon, Porto Alegre, no 49, julho-dezembro, 2010, p.69 - 94 
apresentado no segundo livro da Poética como a melhor comédia? Um tipo de comédia "burguesa", "gentil" e graciosamente divertida, que terá seu auge uma geração após a morte de Aristóteles com o que chamamos Comédia Nova, mais bem representada por Menandro? Ou pelo tipo de comédia que era muito mais violenta, do tipo que conhecemos sobretudo por Aristófanes, ou seja, a Comédia Antiga? Tentar fazer a melhor escolha interpretativa não é uma questão puramente histórica apenas, mas também uma questão filosófica muito interessante, como veremos, uma vez que ela nos põe o problema da natureza do riso e o da relação entre ética e (aquilo que nós chamamos hoje) estética.

À primeira vista, parece que Aristófanes é tido por Aristóteles em alta conta, uma vez que seu nome surge em analogia com o de Sófocles, que parece ser o poeta trágico preferido de Aristóteles (ou pelo menos um dos preferidos, já que ele parece estimar muito Eurípides, como ficar claro especialmente no capítulo 14): "Em um aspecto, Sófocles é o mesmo de imitador que Homero, pois ambos imitam pessoas admiráveis, mas em outro aspecto ele é como Aristófanes, pois ambos representam pessoas agindo e fazendo coisas" $(3,1448 \mathrm{a} 25-28)$. Mas muitos intérpretes negaram que essa passagem tenha um peso especial, uma vez que Aristóteles poderia ter mencionado Aristófanes porque seu nome era conhecido. Pois em uma passagem da Ética Nicomaquéia, ele se refere explicitamente à chamada "Comédia Nova", e parece preferi-la à "Comédia Antiga" de Aristófanes. Nessa passagem, Aristóteles apresenta a eutrapelia (eutrapelia) como uma virtude que é o meiotermo entre a bufonaria (bôlomochia) e a grosseria, e associa a ela o tato (epidexiôtês), traçando um paralelo entre a comédia "velha" e a "nova": "o tato é próprio a esta constituição: é característico de uma pessoa de tato dizer e ouvir as coisas que são apropriadas a um homem bom e livre. Pois há certas coisas que são apropriadas para tal pessoa dizer e ouvir a fim de diversão, e a diversão de um homem livre difere da do escravo, e a de uma pessoa educada da de uma não educada. Também se pode ver isso a partir da antiga e da nova comédias: para os escritores antigos, a linguagem vulgar (aischrologia) era o engraçado, ao passo que os novos preferiam a insinuação (hyponoia), o que faz muita diferença no que respeita a decência (euschêmosunê)" (Ética Nicomaquéia, IV 14, 1128a16-25). Como Aristóteles parece oferecer aqui uma analogia a virtude da eutrapelia e a insinuação da comédia "nova", parece completamente claro que ele também prefira esse tipo de comédia ao antigo estilo, à comédia "antiga". Conseqüentemente, deve-se entender o que Aristóteles diz sobre a comédia na sua Poética de acordo com o que ele diz sobre a virtude da "eutrapelia", e daí tentar de alguma forma alinhar sua definição de comédia no quinto capítulo da Poética com sua preferência pela "nova" comédia. Contudo, penso que essa interpretação, bastante difundida (defendida por Bywater e Else e, mais recentemente, com outros argumentos, por Halliwell, 1986, pp. 266-276 e 2008, pp 307-331, e Schmitt, 2008, pp. 304-321) é uma tentação a que devemos resistir.

Num plano geral, há dois argumentos muito poderosos contra tal visão (que já foram apresentados por Cooper, 1924; cf. também Heath, 1989). Em primeiro lugar, o próprio Aristóteles diz na Poética que "a correção na ética e na poética não é a mesma" (25, 1460b13-14). Não há razão, portanto, para pensar que aquilo que Aristóteles considera correto ou adequado na ética, ou no mundo real, também o deva ser na poesia. Na verdade, contrariamente ao que é suposto por esses intérpretes, Aristóteles não estabelece, na Ética Nicomaquéia, uma analogia entre ética e comédia, mas simplesmente dá a seus leitores um exemplo claro da distinção entre "linguagem vulgar" eutrapelia, ao referir-se a esses dois tipos de comédia. Nada é dito sobre o valor que Aristóteles atribuía a elas ou a preferência que ele teria tido por uma delas. O segundo argumento da provém da passagem já citada da

Organon, Porto Alegre, $n^{\circ} 49$, julho-dezembro, 2010, p.69 - 94 
Política (VII 17). Nela, Aristóteles aceita, sem crítica alguma, o fato de que homens cidadãos e adultos possam assistir a espetáculos de invectivas jâmbicas e comédias. Mas isso soaria muito estranho, se nós aceitarmos a leitura que faz um paralelo estrito entre eutrapelia e o humor de insinuação da "nova" comédia. Pois como devemos entender que a pessoa "livre" e "nobre", descrita na Ética Nicomaquéia, poderia agora, quando descrita como o bem cidadão de uma cidade idealmente perfeita, assistir a espetáculos de poesia jâmbica que são repletos de "linguagem vulgar"?

Eu gostaria, agora, de argumentar mais especificamente contra a idéia de que, no caso da comédia, havia dois tipos de geloion ("risível" e "ridículo"). Como a definição de comédia no quinto capítulo da Poética claramente implica, o geloion no teatro é de um só e seus "tipos" são variações de grau.

Lida do ponto de vista padrão, a passagem recém citada da Política também poderia ser entendida como implicando que os cidadãos podem assistir a espetáculos de invectivas jâmbicas, que certamente são fonte de risada excessiva, e também de comédias, que podem perfeitamente ser de um tipo muito diferente. Mas, na verdade, o texto não permite de modo algum esse entendimento. Certamente, Aristóteles traça uma diferença entre esses dois gêneros de poesia, mas, como eu ainda explicarei, não há oposição entre esses dois gêneros. Como Aristóteles diz exatamente naquela oração, os cidadãos podem assistir a esses espetáculos, desde que "sua educação os (tenha feito) imunes ao dano que provém de tais tipos de poesia”. Isso implica que ambos os gêneros são danosos para os jovens, pois eles têm em comum, devemos supor, a mesma propriedade perigosa. Uma suposição lógica que se revela verdadeira, caso se leia o restante da passagem em que Aristóteles explica que aquilo que os jovens vêem pela primeira vez vai impregná-los pelo resto de suas vidas, e disso conclui que "qualquer coisa vulgar (phaulos), especialmente se contém depravação (mochtêria) ou malevolência, deve ser feita alheia aos jovens" (Política VII 17, 1336b3335). Isto é, tanto invectivas jâmbicas quanto comédias contêm depravação ou malevolência, razão pela qual ambas devem ser proibidas aos jovens. Em outras palavras, não se espera que a comédia forneça o mesmo tipo de piadas de eutrapélicas que Aristóteles defende na Ética Nicomaquéia.

Entretanto, a passagem do quarto capítulo da Poética sobre o Margites oferece um argumento muito forte contra a interpretação padrão que eu estou pondo em causa. Nessa genealogia da comédia, Aristóteles diz o seguinte:

\footnotetext{
A poesia, então, dividiu-se em dois tipos, segundo a natureza do poeta. Pois os poetas mais sérios representavam ações belas e ações de homens de tal tipo, ao passo que os de natureza menos exaltada representavam a natureza homens inferiores, primeiramente escrevendo sátiras, assim como os outros primeiramente escreviam poemas e eulogias. Antes de Homero, sem dúvida, não podemos nomear nenhum poema de tal tipo, embora houvesse provavelmente muitos poetas satíricos, mas, começando a partir de Homero, há por exemplo seu Margites e outros poemas similares. O metro jâmbico foi ajustadamente introduzido nesses poemas, e é por isso que eles ainda são jâmbicos, porque era o metro em que eles escarneciam uns dos outros. Dos antigos, alguns escreviam versos heróicos e outros, jâmbicos. E, assim como Homero era o poeta supremo no estilo sério [...], ele também foi o primeiro a estabelecer as linhas principais da comédia, dramatizando não a invectiva, mas o ridículo/risível (ou: não compondo invectivas, mas dramatizando o geloion: ou psochon alla to geloion dramatopoiêsas). Seu Margites está para a comédia assim como a Ilíada e a Odisséia estão para a tragédia (1448b24-1449a2).
}

De acordo com a interpretação padrão, não há dúvida de que as linhas 37-38 deveriam ser entendidas com o sentido de que Homero adumbrou as linhas da comédia "dramatizando não a invectiva, mas o risível". Com esta tradução, devemos entender que 
Homero adumbrou a comédia ao abandonar o modo como a poesia invectiva se caracterizava, isto é, como um modo essencialmente malevolente e malicioso de rir de alguém, por dramatizar o riso, isto, é um tipo de riso diferente do riso implicado na primeira forma. Aristóteles não caracteriza aqui (nem em nenhum outro lugar da Poética) o que exatamente significa o geloion na comédia, mas, como sabemos que o Margites era um tipo de épica burlesca, temos todas as razões para pensar que o riso do burlesco era do mesmo tipo do riso defendido na Ética Nicomaquéia. Segundo outros (já em Vahlen, mas mais recentemente Heath, 1989), penso que isso desconstrói totalmente não apenas essa proposição, mas também todo o contexto. De início, a invectiva é uma candidata muito fraca para ser oposta ao geloion, dado que se supõe que ela também seja divertida. Em seguida, "invectiva" aqui sem dúvida significa não a invectiva de modo geral, mas um gênero de poesia; portanto, é bastante improvável que Aristóteles quisesse dizer que Homero não dramatizasse o gênero da invectiva. Com efeito, a oposição não é entre invectiva e geloion, mas entre os modos de composição: por recitação ou por dramatização. Visto que um poema invectivo era recitativo, o modo como Homero adumbrou a comédia foi dramatizando o geloion. Por isso, a tradução mais correta deveria ser: "Homero não compunha invectivas, mas dramatizava o geloion". O Margites não era uma invectiva no sentido de pertencer ao gênero "invectiva jâmbica", mas isso não significa que seu geloion era de um tipo diferente do geloion suscitado por esse tipo de gênero poético.

Antes de voltar ao Margites e ver como essa leitura pode aplicar-se a ele, há uma outra passagem que precisa ser lida em paralelo a essa. Acabamos de ver que, no quarto capítulo, se diz que o Margites adumbrou a comédia, ou foi o primeiro passo para a descoberta da comédia porque ele é o primeiro "drama" do geloion, ao passo que a invectiva jâmbica não é dramática. No quinto capítulo da Poética, Aristóteles acrescenta a essa genealogia da comédia um segundo passo: "a composição de enredos (mythous) veio originalmente da Sicília e, entre os poetas Atenienses, Crates foi o primeiro a compor estórias ou enredos universais (katholou), abandonando a forma (idea) da invectiva jâmbica (5, 1449b6-7). Aqui, está absolutamente claro que a oposição entre invectiva e comédia se dá entre a oposição entre o caráter particular da invectiva e o caráter universal da comédia, e não tem relação com a natureza do geloion. A questão do sentido exato dessa oposição, que deve ser lida em paralelo com o capítulo nove (e talvez com o dezessete), é disputada, e retornarei a ela adiante. Contudo, o que é importante para o meu propósito é que, aqui, novamente, a comédia não é oposta à invectiva em virtude de um tipo diferente de geloion, mas porque elas não têm o mesmo modo de apresentar as coisas: a invectiva é poesia recitativa, ao passo que a comédia é dramática; a invectiva é poesia sobre particulares, ao passo que a comédia é sobre "universais".

A isso pode-se adicionar dois detalhes muito reveladores dos capítulos quarto e quinto da Poética, já citados, que confirmam a leitura que estou defendendo. O primeiro é o exemplo de geloion dado no quinto capítulo: "o geloion é um certo hamartêma ou sinal de vergonha (aischos) que não envolve dor ou morte, como é imediatamente evidente no caso da máscara da comédia: ela é feia (aischron) e distorcida, mas não envolve dor" (1449a3237). Já se pensou, na linha da interpretação padrão, que o geloion a que se refere aqui é precisamente o tipo defendido na Ética Nicomaquéia, uma vez que não envolve dor, não inflige dano nenhum à pessoa de que se zomba. Mas, como a maioria dos intérpretes corretamente viu (mesmo aqueles que defendem a interpretação padrão), a oposição desta passagem se dá entre o "erro" que causa dor profunda e morte, como é o caso da tragédia, e o "erro" que não leva a tal dor ou à morte, como é o caso da comédia. E o que mostra o 
exemplo da máscara é exatamente esse fato: contrariamente às máscaras trágicas, as máscaras cômicas não expressam profunda agonia ou dor física. Mas elas também não mostram nenhum sinal de um sorriso "eutrapélico" e gentil que não causaria nenhum dano "moral" também; pelo contrário, elas geralmente expressam um sorriso zombador muito malevolente e bastante forte.

Uma segunda prova para a minha leitura provém da muito famosa (desde Nietzsche), e no entanto muito obscura, menção ao ditirambo e às "canções fálicas" que estão na origem da tragédia e da comédia. Seja qual for a relação entre esta origem (que parece ser mais "histórica") e a anterior (que parece ser mais "teórica"), a menção às "canções fálicas" confirma a idéia de que o geloion cômico não pode ser de um tipo diferente do geloion da poesia invectiva. Não dispomos de muitos textos antigos sobre essas canções, mas a famosa passagem dos Acarnenses (vv. 263-279), em que o personagem principal canta tal canção, claramente demonstra que essas canções eram repletas de indecência e despudor - apesar do fato de ser uma paródia do ritual. E um fragmento de Heráclito (15 Diels-Kranz) também dá a entender que essas procissões em honra a Dionísio, e "os hinos às genitálias" (que bem podiam ser estes phallika ou, pelo menos, não fundamentalmente diferente deles) eram acompanhados de "atos vergonhosos", provavelmente atividades sexuais e orgiásticas. Portanto, é muito provável que as "canções fálicas" fossem algum tipo de canções bastante obscenas, o que implica que elas eram repletas de "linguagem vulgar" - que é precisamente apresentada como o contrário da "eutrapelia" que Aristóteles defende na sua Ética Nicomaquéia! Poder-se-ia responder a isso que essas canções fálicas são apresentadas como a origem da comédia, o que não significa necessariamente que a comédia deva prover seus espectadores do mesmo tipo de geloion que essas canções o fazem. Entretanto, Aristóteles não mostra nenhum sinal de traçar uma linha divisória clara entre essas canções e a comédia; pelo contrário, o leitor tem a impressão de que toda essa história apresenta forte continuidade, pelo menos no que diz respeito a esse aspecto.

Contudo, mesmo que se aceite a leitura que defendo, como se pode aplicá-la ao Margites? Pois, como normalmente e apresentado, o Margites não era uma invectiva contra alguma pessoa em particular, nem uma invectiva dramática dos feitos de algumas pessoas "más", uma apenas um tipo de burlescaria agradável e gentil; quase certamente, o "herói" era um estúpido (margos significa tanto "estúpido quanto "inábil”), mas não há nenhuma indicação, a partir dos fragmentos que possuímos, de nenhuma invectiva contra ele. Mas essa apresentação mais difundida é apenas uma suposição: se não temos nenhuma prova clara de seu caráter invectivo a partir de nenhum fragmento remanescente, não se segue necessariamente que ele absolutamente não tinha esse caráter e que seu humor era "eutrapélico". Se nos apoiarmos no quarto capítulo da Poética, que é nossa única base segura para avaliar o modo como Aristóteles considerava que o Margites adumbrava a comédia, parece-me que o contrário é muito mais provável. Sem entrar em todos os detalhes dessa difícil passagem, penso que as duas orações principais apóiam fortemente minha leitura. A primeira diz que o primeiro exemplo "desse tipo de poiêma" é "o Margites de Homero e outros poemas do tipo, nos quais, por causa de sua adequação, ocorreu o metro jâmbico" (1448b30-31). O que diz Aristóteles, creio eu, não é que o Margites seja uma invectiva jâmbica, mas que o metro jâmbico também ocorreu nele, ou nele se desenvolveu por causa da sua adequação, isto é, porque esse próprio tipo de metro expressa o caráter invectivo desse tipo de poema (ou de partes desse poema). Essa leitura da oração, que eu penso ser a mais natural, confirma a leitura que tenho apresentado até agora. E ela também explica como Aristóteles pode concluir essa genealogia homérica antecipando o que ele

Organon, Porto Alegre, $n^{\circ} 49$, julho-dezembro, 2010, p.69 - 94 
demonstrará na seqüência - nos capítulos 5 e 9, sobre a universalidade, e no 26, sobre a superioridade da tragédia sobre a épica -: "quando a tragédia e a comédia surgiram, aqueles que se inclinavam para cada um dos tipos de poesia se tornaram, de acordo com suas naturezas, poetas de comédia em vez de invectivas ou de tragédia em vez de épica" (1449a2-5). Caso se pense que o Margites era de natureza totalmente diferente da invectiva, esta conclusão seria muito estranha, pois a poesia cômica correspondente à (ou, mais precisamente, "provinda da") épica não é a invectiva jâmbica, mas a poesia do tipo do Margites! Mas essa conclusão soa perfeitamente bem quando se percebe que o Margites é poesia precisamente do mesmo tipo da poesia jâmbica ou, pelo menos, que ambos têm em comum a propriedade de serem de caráter invectivo. O que diz Aristóteles, portanto, é que poetas teleologicamente realizados escrevem agora tragédias e comédias em vez de épicas e poemas invectivos (tanto invectivas jâmbicas quanto poemas como o Margites), porque elas são formas de poesia maiores e mais estimadas" (1449a5-6). E elas o são, ele nos dirá, porque são mais universais; e porque contam com outros componentes, como espetáculo, dança e música (cf. capítulo 26), elas são capazes de suscitar um efeito muito mais prazeroso na audiência. Se seguimos a lógica do nosso texto, nada indica que a comédia é agora "mais estimada" do que as sátiras invectivas porque elas eram de um tipo diferente de geloion.

Respondamos, agora, a um outro (e último) argumento contrário: como devemos entender o lugar de Aristófanes nessa história? A interpretação padrão tem aqui uma história que parece ser muito clara: como é o caso, indubitavelmente, da passagem da Ética Nicomaquéia, Aristóteles sem dúvida prefere a "nova" comédia (aqui, isso é o que os historiadores bizantinos chamam comédia "média", que era escrita na época de Aristóteles), cujo objetivo é alguma forma de insinuação, à "antiga" comédia e sua linguagem despudorada (aischrologia). Visto que essa "nova" comédia se refere aos dramaturgos cômicos da época de Aristóteles (os dramaturgos da comédia "média"), eles devem ser considerados os modelos de boas comédias para Aristóteles, assim como Sófocles e Eurípides são, obviamente, considerados os melhores dramaturgos trágicos. Certamente, Aristóteles menciona na sua Poética o maior nome da Comedia Antiga, Aristófanes, mas isso não significa, de modo algum, que ele seja seu escritor cômico favorito. Ao dizer que poderíamos comparar Homero a Aristófanes porque ambos representam pessoas em ação (cf. 3, 1448a27-28), Aristóteles provavelmente estaria usando o nome de Aristófanes porque ele era bem conhecido por sua audiência (cf. Halliwell, 1986, pp. 273-274).

Com efeito, creio que Aristóteles não diferencie claramente esses dois tipos de comédia, assim como ele não distingue dois tipos de geloion, e que, portanto, não há razão para excluir Aristófanes da sua lista putativa de melhores comediógrafos. Em primeiro lugar, devemos notar que, na passagem da Ética Nicomaquéia em Aristóteles evoca essa distinção, ele na verdade diz que, no caso da comédia "antiga", "a linguagem vulgar (aischrologia) era o que o engraçado," enquanto que, no caso da "nova" comédia, o engraçado "é mais a insinuação" (mallon hê hyponoia) (1128a23-24). Se o texto é lido como está (contrário ao que a maioria das traduções sugere), então Aristóteles não diz que aquilo que provoca o riso na comédia "nova" é justamente a insinuação, ao invés da linguagem vulgar, que implicaria que ele distingue os dois tipos de geloion, mas sim que ela contém mais insinuação - o que significa que ela também contém alguma "linguagem vulgar", de modo que nós poderíamos fazer o caminho contrário e concluir que a comédia "antiga" continha alguma insinuação também. Nenhuma grande novidade nisso: o próprio Aristófanes reprova outros comediógrafos por encenarem "coisas más (kaka), assunto vulgar (phorton) e bufonaria

Organon, Porto Alegre, no 49, julho-dezembro, 2010, p.69- 94 
(bômologeumata)" demais (Paz, 748). Não digo, entretanto, que algumas peças de Aristófanes devam ser consideradas parte da Comédia Nova (como foi proposto por Schmitt, 2008, pp. 308-313). O que acontece, mais simplesmente, é que Aristóteles não traça uma diferença clara entre esses dois períodos da comédia. Porém não é apenas isso: na verdade, Aristóteles não opõe totalmente os dois tipos de geloion. É verdade que Aristóteles diz que a "eutrapelia" não se destina a ferir a pessoa de quem se zomba, o que aparentemente não é o caso da "linguagem vulgar". Mas, contrariamente o que se diz de costume, isso não significa que a insinuação também seja completamente inofensiva, pelo menos de acordo com a nossa sensibilidade moderna. Infelizmente, Aristóteles não explica o que devemos supor ao que exatamente se refere essa "insinuação". Todavia, na Retórica, ele distingue muito bem "linguagem vulgar" e ironia (eirôneia), dizendo que "foi dito nos livro sobre poesia quantos tipos de geloion há. Alguns são adequados aos homens livres, outros não; trata de escolheres o que é adequado para ti. A ironia é mais adequada ao homem livre de que a bufonaria" (III 19, 1419b6-8). Há de se notar que a distinção entre escravos e cidadãos livres também faz parte do argumento da passagem da Ética Nicomaquéia que mencionamos: ainda que ironia possa não ser sinônimo de eutrapelia, é absolutamente evidente que ela é um conceito muito próximo de eutrapelia, ou uma parte dela. Então, de acordo com a leitura padrão, a implicação disso seria que a ironia não deve ser entendida como um componente de nenhum tipo de invectiva ou crítica grotesca de alguém. Mas isso não é o que diz Aristóteles; o que ele diz clara e explicitamente, em outra passagem da Retórica, é que "a ironia é algo desprezível (kataphronêtikon)" (II 2, 1379b31).

Aristóteles insiste também, nas duas passagens da Retórica em que ele indubitavelmente se refere à sua Poética (ao segundo livro, como devemos supor), que ele tratou ali dos vários tipos de piadas (em grego: ta geloia). De acordo com a interpretação padrão, isso significa que ele apresentou tipos de comédias diferentes e opostos, tais como comédias de estilo irônico e comédias de linguagem vulgar. Entretanto, traçar uma distinção tão clara entre as comédias "antiga" e "nova" não é prudente, se lemos os textos literalmente, mas também, e de modo mais importante para o nosso entendimento filosófico do riso, não há oposição entre tipos de riso. Os vários tipos de riso devem ser subsumidos sob o gênero riso, que sem dúvida se refere, se estou certo até aqui, à agressividade e à ofensa, de modo que os vários "tipos” de riso, ou piadas, correspondem aos vários graus de agressividade e ofensa. Como outros intérpretes disseram, não há diferença significante entre a concepção aristotélica de riso e a de Hobbes (Skinner, 2002). No mundo real, insinuação e ironia (que poderiam ser descritas como zombaria gentil, mas ainda um pouco ofensivas) são, certamente, mais apropriadas "no que diz respeito à decência" (1128a25) do que insultos (isto é, zombaria fortemente ofensiva). Mas, como eu disse no início, não há razão para pensarmos que este também seria o caso no teatro. Finalmente, portanto, também não há razão para pensarmos que Aristófanes, que empregava ambos os tipos de zombaria, como ele mesmo se apresenta, não fosse muito admirado por Aristóteles.

A segunda característica principal da comedia é a causa do geloion: o hamartêma. Reconhece-se amplamente que a causa do geloion seja a contraparte da famosa passagem do capítulo 13 da Poética, na qual Aristóteles repete que a hamartia (ou o hamartêma) é a causa da tragédia, ou seja, a causa pela qual o "herói" da tragédia experimenta a queda a partir de sua boa sorte, ou felicidade (eutychia), para a desgraça (dystychia). O problema, porém, é que Aristóteles jamais explica em que essa "falha" ou "erro" consiste exatamente. É uma falta moral? Ou apenas uma ação equivocada? Ou um erro intelectual? A maioria dos intérpretes, atualmente, parece ter aceito que a hamartia não deve ser entendida como um 
conceito rígido, nem como possuindo um significado exclusivo: a hamartia é justamente o que calha de ser o "erro" ou "falta" que á causa da queda trágica do herói. Como não há motivo para traçar um paralelo estrito entre tragédia e comédia em relação a esse ponto, eu sugiro que entendamos a definição do geloion (como "um certo erro (hamartêma) ou sinal de vergonha (aischos) que não envolve dor ou morte") da mesma maneira, referindo-se hamartêma mais provavelmente a erros no sentido de ações ou decisões equivocadas, e aischos, por sua vez, a "defeitos" ou "faltas" mais genéricas. Mas, seja qual for o sentido exato da primeira palavra, a segunda fornece uma confirmação adicional para minha interpretação do geloion.

A palavra aischos, "feiúra", é uma palavra bastante rara que Platão e Aristóteles opõem a kallos, "beleza". A "beleza", como é explícito em Platão, pode ser física ou "moral" e, no caso da comédia, é fato que encontramos exemplos de ambos os usos nas comédias gregas que conhecemos. Mas o tipo de "feiúra" a que Aristóteles se refere no exemplo da máscara é claramente feiúra física: a máscara é a mimêsis, por assim dizer, de um rosto feio e distorcido (note-se que, em grego, rosto e máscara são a mesma palavra: prosopon). Isso indica claramente o tipo de geloion implicado aqui: fazer graça de um rosto feio produz um riso bastante desdenhoso! Assim, se a máscara deve ser tomada como um "exemplo óbvio" de como devemos entender o geloion em geral, não há dúvida de que a agressividade, o desprezo e o desdém devem ter um papel central aqui.

\section{EMOÇÕES E KATHARSIS}

Compaixão e medo (e talvez outras emoções do mesmo tipo) são as emoções envolvidas na tragédia. A comédia compartilha com a tragédia todas as seis "partes constitutivas" (enredo, dicção etc.), enumeradas no capítulo 6, assim como três dos quatro requisitos (também "partes" no vocabulário de Aristóteles) de um enredo (universalidade, unidade e totalidade). E ela, com toda a probabilidade, também compartilha com a tragédia o objetivo último de uma peça de teatro: a catarse de certas emoções. Portanto, é inevitável perguntarmo-nos qual emoção, ou emoções, está envolvida na comédia. Infelizmente, esse talvez seja um dos pontos mais frustrantes em qualquer tentativa de reconstruir a teoria aristotélica da comédia: não temos nenhum indício absolutamente confiável disso e nenhuma afirmação feita pelo próprio Aristóteles sobre esse tema. Não deixa de ser surpreendente-e muito estranho, deve-se admitir - que ele não mencione nenhuma emoção na definição de comédia dada no capítulo 5 da Poética.

A bem da verdade, encontramos as emoções da comédia mencionadas na definição de comédia dada pelo Tratado Coisliniano: "a comédia é uma mimêsis..., alcançando, através do prazer (hêdonê) e do riso (gelôs), a catarse de tais emoções". Mas, como a maioria dos especialistas defendeu (cf. Janko, 1984; Fortenbaugh, 2003), essa é umas das afirmações mais estranhas encontradas nesse texto, uma vez que não temos nenhum texto de Platão ou Aristóteles em que prazer e riso seriam considerados emoções, como a compaixão, o medo e semelhantes. Certamente, como lágrimas são descritas (especialmente por Platão) como uma expressão corporal de compaixão, o riso deve ser expressão corporal da mesma emoção (cf. Halliwell, 2008, acerca dos aspectos corporais do riso).

Se minha análise estiver basicamente certa até este ponto, parece-me que já descobrimos o arcabouço a partir do qual podemos reconstruir o que Aristóteles pode ter dito sem corrermos um risco muito grande. Pois, se a agressividade é uma propriedade básica, essencial do riso, é difícil fugir à conclusão de que algum tipo de emoção (ou

Organon, Porto Alegre, $n^{\circ} 49$, julho-dezembro, 2010, p.69 - 94 
emoções) agressiva deve ser a emoção (ou emoções) própria da comédia; e, se for assim, a raiva (orgê) e a inveja (phthonos), que são analisadas na Retórica juntamente com a compaixão e o medo, aparecem como as candidatas mais óbvias (como já foi sugerido por Cooper, 1924, p. 67, e seguido por Lucas, 1968, p. 288). Como Aristóteles não diz absolutamente nada sobre a comédia ou sobre o riso nesses capítulos da sua Retórica, seria arriscado elucubrar com maior precisão acerca dessas supostas "emoções cômicas". Mas há, eu gostaria de sugerir, alguns argumentos muito fortes que sustentam essa idéia genérica e nos permitem tirar algumas conclusões, também genéricas, a respeito do entendimento filosófico que Aristóteles tinha da comédia e da sua importância para questões éticopolíticas.

O primeiro argumento vem do Filebo de Platão. Numa passagem bastante famosa, Sócrates tenta explicar a mistura de prazer e dor (47d-50e). Mais precisamente, ele tenta explicar como e por que podemos sentir prazer e dor no mesmo momento, tomando o riso cômico como um caso em que experimentamos essa mistura, assim como também é o caso "dos espetáculos trágicos onde as pessoas ao mesmo tempo têm prazer e choram". No caso da comédia, phthonos, "malícia" ou "inveja" (o sentido exato é controverso), é a emoção dolorosa que causa o prazer cômico (cf. 48b e 50a); aqui, na comédia, phthonos é o equivalente da compaixão na tragédia (Platão não menciona "compaixão" na passagem, mas "arrependimento" (pothos) e "lamentação" (thrênos), que se referem ao mesmo fenômeno): essas são as emoções dolorosas que paradoxalmente temos prazer em experimentar quando vamos ao teatro (ou lemos uma peça). Os detalhes desse texto famoso são bastante difíceis de interpretar e é lamentável que Aristóteles não pareça referir-se a ele em lugar algum, mesmo que implicitamente - e há uma dificuldade adicional: se interpretamos phthonos como "malícia", como a ligaremos à Retórica de Aristóteles, onde significa "inveja" claramente? Contudo, penso que essas não são razões determinantes para que sejamos relutantes em usar esse texto a fim de entendemos melhor o que Aristóteles poderia ter dito acerca da emoção (ou emoções) evocada por um enredo cômico. Enfim, não temos também nenhum traço de crítica de Aristóteles contra tal visão. E, se levamos em conta o fato de que Aristóteles jamais critica a descrição platônica do fenômeno da tragédia (isto é, as emoções e o prazer paradoxal etc.), não há razão para pensarmos que ele o teria feito no caso da comédia. Certamente, a Poética de Aristóteles pode ser lida como uma resposta ao banimento dos poetas da Kallipolis na República de Platão, mas isso nada tem a ver com sua descrição dos gêneros poéticos. Além do mais, Sócrates parece apresentar essa emoção cômica se ela fosse evidente: Protarco diz repetidamente que ele não compreende como a mistura de emoções pode ocorrer, mas nada diz acerca das emoções. E há uma razão muito boa para isso: o riso é, em Homero ou Aristófanes (no mais das vezes), um riso desdenhoso e maldoso sobre outras pessoas. Como Aristóteles dá por aceita a descrição básica das emoções trágicas por Platão, é mais lógico assumir que ele, muito provavelmente, fez o mesmo em relação à emoção (ou emoções) cômica.

Meu segundo argumento, mais positivo, relaciona-se com a questão da katharsis que eu apresentei brevemente. $\mathrm{O}$ tema da katharsis é provavelmente um dos mais controversos de toda a filosofia antiga; contudo, a única coisa que a maior parte dos especialistas aceita como certa é que Aristóteles apresenta a katharsis como o fim último da tragédia. Mais precisamente, o objetivo do poeta é escrever um enredo (que é, metaforicamente falando, a "alma" da tragédia) que permita (através das "partes" do enredo: peripécia, reconhecimento e sofrimento) evocar as emoções trágicas, compaixão e medo, a fim de "realizar a katharsis de tais emoções". No entanto, a katharsis não é usada depois disso no texto que temos da

Organon, Porto Alegre, $n^{\circ} 49$, julho-dezembro, 2010, p.69 - 94 
Poética (a segunda ocorrência, em 17, 55b15, aparece em outro contexto) e não é dada ali como o fim da comédia. Há, porém, cinco outras passagens que sugerem, ou dizem explicitamente, que Aristóteles pensava que a katharsis era o fim último da comédia também. Vejamos os textos.

O primeiro texto é a famosa passagem da Política em que Aristóteles diz querer explicar "mais claramente" o que ele entende por katharsis "nos livros sobre poesia" (VIII 7, 1341b39-40). Como não temos nada parecido no nosso primeiro livro da Poética, a sugestão é que a katharsis poderia, ou deveria, ter sido estudada no segundo livro (supondo que Aristóteles tenha mantido sua palavra). Isso implicaria que não havia apenas a menção da katharsis cômica, mas também uma teoria ou explicação desse fenômeno deveras obscuro (pelo menos para nós). O segundo texto é a definição de comédia dada pelo Tratado Coisliniano, já citado, que explicitamente apresenta a katharsis como o fim realizado pela mimêsis cômica. Como eu já disse, o texto é provavelmente pouco confiável, pois estranhamente apresenta o riso e o prazer como emoções das quais há katharsis; mas é um fato evidente que a idéia genérica de uma katharsis cômica veio, de uma forma ou de outra, do próprio Aristóteles ou, pelo menos (no caso de se pensar que o autor do Tratado era um falsário), que tal característica era comumente aceita na Antiguidade. Nossos terceiro e quarto textos são muito mais elaborados. Jâmblico e Proclo também falam explicitamente de uma katharsis cômica. Para Jâmblico (De Mysteriis, I 11, 54-56) "quando nós testemunhamos as emoções de outros, tanto na comédia quanto na tragédia, nós cessamos nossas emoções, produzimo-las mais moderadamente e nos purgamos [ou "as purificamos": apokathairein]". E, segundo Proclo (In Platonis Rempublicam, 1. 49, 14-15), “...através delas [i.e. da tragédia e da comédia], satisfazer (apopimplanai) as emoções em justa medida”. Não é fácil utilizar essas passagens para entender a concepção aristotélica de katharsis, dado que seus autores bem poderiam ter dado suas próprias interpretações desse conceito - particularmente, a idéia de moderar as emoções, presente em ambos, soa bastante aristotélica, mas os textos de Aristóteles não nos fornecem nenhuma prova de que de que ele realmente tivesse essa noção do processo catártico. De qualquer forma, parece difícil negar que Jâmblico e Proclo tenham lido, quer no próprio Aristóteles (seja no segundo livro da Poética, seja no livro Sobre os Poetas que Aristóteles publicou para um público exterior à sua escola), quer em algum outro relato ou sumário antigo, que Aristóteles tinha algo a dizer sobre a katharsis e as emoções cômicas.

Por fim, o último texto, que é o mais interessante para meu propósito. Trata-se de um fragmento de um papiro de Herculano, descoberto recentemente, que contém o livro de Filodemo Sobre a Poesia: "a poesia é algo útil no que diz respeito a... [à virtude?], purificando (kathairousa), [como] dizemos nós, a parte... [da alma?]. Há loucura nas almas dos mais sábios, e intemperança nas dos mais temperantes. Do mesmo modo, há temores nos bravos, e emoções vis (phthonoi) nos magnânimos" (texto reconstruído por Nardelli, 1978). Assim como os dois textos anteriores, este texto dificilmente se referiria a outra pessoa além de Aristóteles. E, mesmo com suas dificuldades (em particular, a menção da loucura e da intemperança), é altamente significativo que phthonos ocorra aí juntamente com o medo. Se lemos essa oração como uma referência à tragédia e à comédia, que é a leitura mais natural, a inveja (ou malícia) aparece como uma (ou a?) emoção cômica, do mesmo modo que o medo é uma das emoções da tragédia. Pode-se resistir à tentação de considerar-se esse texto uma citação provinda diretamente de Aristóteles, uma vez que a passagem poderia apenas refletir a interpretação que faz Filodemo de um texto aristotélico (Sobre os Poetas também, provavelmente). Contudo, seja qual for a decisão interpretativa,

Organon, Porto Alegre, no 49, julho-dezembro, 2010, p.69-94 
ela tende muito fortemente a indicar que temos aqui a emoção que Aristóteles poderia ou deveria ter apresentado como própria da comédia.

Penso que há uma passagem na nossa Poética cuja interpretação é difícil, se não se tem em mente esse arcabouço. No final do capítulo 13, Aristóteles diz que "esse não é o prazer que resulta da tragédia; ele é mais característico da comédia. Na comédia, mesmo pessoas que são os piores inimigos no enredo, como Orestes e Egisto, saem reconciliados no final, e ninguém é morto por ninguém" (1453a35-39). Como quer que se entenda todo o contexto da passagem, parece que a explicação óbvia do contexto seja a seguinte: tal comédia (aqui, podemos supor, um peça burlesca sobre a tragédia de Orestes) é engraçada porque os espectadores podem desprezar um ato tão vergonhoso e rir dele, como se fosse cometido por um Orestes rebaixado, que no final se concilia com o assassino de seu pai, em vez de matá-lo por vingança. Como o prazer próprio da poesia é suscitar as emoções próprias de cada gênero, seria de se esperar que esse exemplo seja coerente com a minha análise anterior: a prazer próprio da comédia vem, paradoxalmente, através da mimêsis (como diz Aristóteles em 8, 1453b12) das emoções "cômicas", certa baixeza ou (e?) desprezo ou desdém para com alguém.

Mesmo que não haja nenhuma menção explícita a Platão na Poética, me parece além de qualquer dúvida Aristóteles tenha reabilitado a tragédia contra Platão. E, como Platão condenou a tragédia essencialmente por razões morais, é razoável supor (mesmo que Aristóteles não o diga explicitamente) que nós devamos ler essa reabilitação com as mesmas razões. E, como muitos estudiosos defenderam, desde a Renascença, também é razoável supor que a katharsis tivesse um papel central aqui. Quer seja ela a "purificação" da compaixão e do medo, ou seja, de modo bastante impreciso, a transformação dessas emoções em virtudes através da sua moderação, quer seja ela a "purgação" dessas emoções, isto é, a libertação de perturbações emocionais, nós devemos supor que a tragédia, aos olhos de Aristóteles, desempenhava um papel importante não na educação dos jovens, mas na educação moral "permanente" dos cidadãos adultos. De acordo com a leitura que ofereci, sugiro que entendamos a reabilitação aristotélica da comédia contra Platão da mesma maneira.

Platão diz, no terceiro livro da República (388e-389a), que a obra de Homero deve ser banida, ou no mínimo reformada, pois ela apresenta aos seus jovens leitores o espetáculo de deuses rindo violentamente e zombando severamente das pessoas (como do coxo Héracles). Sendo os deuses (assim como os heróis homéricos) como que os modelos de nossos papéis, os jovens devem ser proibidos de ler esse tipo de estórias. No décimo livro da República (606c), Platão condena a poesia cômica porque seus espectadores, mesmo os moralmente bons, queiram ou não queiram, tendem a representar bufões e tornarem-se tais na vida real. Em ambos os casos, o riso agressivo é condenado, uma vez que se deve evitar representar tais papéis caracteres cômicos, caso se queira ser "justo" ou, mais genericamente, "moralmente bom".

Assim como no caso da tragédia, a resposta de Aristóteles poderia ser a seguinte: assistir a espetáculos cômicos, ou ler peças cômicas, é uma boa ajuda para as pessoas (adultas) consigam ou moderar sua agressividade (que pode incluir raiva e inveja), ou livrarem-se dela ${ }^{2}$.

2 Traduzido por José Baracat Jr. 


\section{BIBLIOGRAFIA}

BERNAYS, Jacob. Ergänzung zu Aristoteles' Poetik. Rheinisches Museum, 8, pp. 561-596, 1853.

COOPER, Lane. An Aristotelian Theory of Comedy. Oxford: Blackwell, 1924.

FLASHAR, Hellmut. Aristoteles, das Lachen und die Alt Komödie. In: S. JÄKEL und A. TIMONEN (orgs.). Laughter down the Centuries I, Turku 1994. Turku: Annales Universitatis Turkuensis, 1994.

FORTENBAUGH, William. An Aristotelian and Theophrastean Analysis of Laughter. In:__. Theophrastean Studies. Stuttgart: Franz Steiner Verlag Wiesbaden, 2003.

GOLDEN, Leon. Aristotle on the Pleasure of Comedy. In: A. O. Rorty. Essays on Aristotle's Poetics. Princeton: Princeton University Press, 1992.

HALLIWELL, Stephen. Aristotle's Poetics. London: Duckworth, 1986.

. Greek Laughter. Cambridge: Cambridge University Press, 2008.

HEATH, Malcolm. Aristotelian Comedy. Classical Quarterly, 39, pp. 244-354, 1989.

JANKO, Richard. Aristotle on Comedy. London: Duckworth, 1984.

. Aristotle on Comedy, Aristophanes and Some New Evidence from Herculaneum. In:

O. Andersen (org). Making Sense of Aristotle's Poetics. London: Duckworth, 2002.

LANZA, Diego. Aristotele, Poetica. Milano: BUR, 1987.

LUCAS, D. W. Aristotle's Poetics. Oxford: Oxford University Press, 1968.

NARDELLI, M. L. La catarsi poetica nel PHerc. 1581. Cronache Ercolanesi, 8, pp. 96103, 1978.

SCHMITT, Arbogast. Aristoteles, Poetik. Berlin: Akademie Verlag, 2008.

SKINNER, Quentin. Hobbes and the Classical Theory of Laughter. In:__. Visions of Politics: vol. III, Hobbes and the Civil Science. Cambridge: Cambridge University Press, 2002.

SUTTON, D. F. The Catharsis of Comedy. Lanham: Rowman \& Littlefield, 1994. 